\title{
ACTIVE METHODS IN TEACHING MEASUREMENT UNCERTAINTY
}

\author{
O. S. Bukrieieva ${ }^{1}$, Ya. S. Medvedovska ${ }^{2}$ \\ Kharkiv National Automobile and Highway University, Yaroslava Mudrogo Str., 25, 61002, Kharkiv, Ukraine \\ Iolga_bukreeva@ukr.net \\ 2yana.brovko@ukr.net
}

\section{Abstract}

The article considers the problem of activation of students' cognitive activity and efficient use of study time while studying by them of the definition of measurement uncertainty and its calculation. Survey of 56 students studying in specialty "Metrology and information and measurement system" demonstrated that $80 \%$ among them assumed this topic to be the most difficult in the course "Principles of metrology", and $60 \%$ answered that they required more time to digest it than provided in the discipline plan. To eliminate this discrepancy, students were proposed with the methods of working with educational materials for independent study with further practice in classroom: supporting signals and blitz games. Such pedagogical methods are focused on gaining a better understanding of theory for the same period. At the second stage the authors asked the students to evaluate those skills they have gained. The survey demonstrated that $30 \%$ of students interviewed found it difficult to calculate measurement uncertainty during classroom and graduation project, as well as when solving application tasks requiring for calculation of uncertainty, when studying interdependent disciplines. $18 \%$ asked that they could not make a budget of uncertainty by themselves. $70 \%$ noted that they wanted to receive more practical examples of solving such tasks. The authors chose the "case study" method, one its prominent feature is the creation of problem situation based on facts of real life or professional activity. The results demonstrated that, subject to static essentiality and compared to the control group, successfulness of learning measurement uncertainty increased by $16 \%$, and quality by $12 \%$.

Keywords: case study, e-learning, measurement uncertainty, project method, reference signal.

\section{Introduction}

Due to the growing competition on the labor market, globalization and intensification of production facilities, the employers prefer to employ those interviewees with practical experience of solving professional tasks. Thus, satisfying the internal requirements of the education system become less important than satisfying the external requirements of the labor market, which considered as a key condition in students teaching process success. This makes the matter of forming students' professional skills essentials more than ever. In addition, such situation changes the familiar roles of student and teacher: the student should become an active participant in the educational process, also, the teacher - should become the organizer of student' cognitive activity, and not just an informant. These factors create a necessity to maximize the efficiency of the study time usage, to teach the students the methods of the independent work, and activation of their cognitive skills considering discipline nature.

A similar task was also identified in the field of teaching metrology in higher education institutions [1-4]. The authors [1] suggest a solution to this task with using innovation technologies teaching and concept of developmental learning, that are based on the formation of skills complex for setting and solving difficult professional problems in conditions of uncertainty. Also, according to the authors, the generalized model of the such learning provides for active students participation in the learning process, ability to apply knowledge in the real conditions; presenting concepts and knowledge in various forms; approach to the teaching as a collective activity, not as an individual activity; accent on the comprehension rather than memorizing. They recommend implementing these principles by using personal-oriented learning, lections-visualizations, case studies, test assessments, block-module learning, projects method, collaborative learning.

The authors [2] support an idea of development of professional student' skill by creating educational and professional fully certain situations (target, content, result and approaches are known), partially certain situations (target and contents are known), and complete uncertain at all (only target is known).

In [4], it was noted that in the educational program in the field of "Standardization and Metrology" more attention should be paid to the study and practical application of the "Guide to the Expression of Measurement Uncertainty" (GUM). And the authors [3] recommend a sequence of studying the error and measurement uncertainty in engineering courses.

Thus, the aim of the research was to identify the degree of effectiveness and feasibility of using elements of innovative and production-oriented technologies, interactive teaching methods, methods for creating educational and professional situations in teaching measurement uncertainty.

\section{Technology of work with education literature}

The concept and procedure for calculating measurement uncertainty is usually presented to students in the form of a lecture with the skills check in practical and laboratory classes.

At the first stage, the study was aimed at revealing the features of students' perception of the theoretical foundations of measurement uncertainty. A survey of 56 students studying in the specialty "Metrology and information-measuring equipment" showed that $80 \%$ of them consider this topic the most difficult in the course "Fundamentals of Metrology", and 60\% said that they need more time to master it than given by the work program of the discipline. To eliminate this drawback, 
students were offered methods of working with educational literature for self-study with subsequent working out in the audience: reference signals and blitz games, which can be applied, including to the GUM text [5], to each of its sections in turn or to allowance [6]. These pedagogical technologies contribute to better memorization and understanding by students of educational material and aim to deepen understanding of the theory at the same time.

Shatalov method of supporting syllabuses was chosen because they are concise, supply material with enlarged didactic units, have a semantic graphic accent, unified symbols and color clarity, are autonomous in separate blocks, are available for reproduction [7].

Examples of tasks for working with educational literature:

"Reference signals". Outline the text with the help of drawings, diagrams, symbols, retell its contents on them (Fig. 1). The accuracy and detail of the reproduction is evaluated.

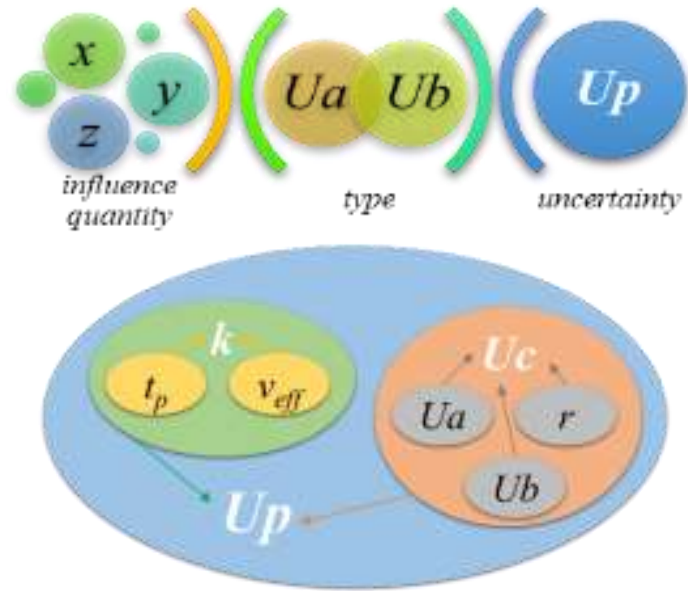

Fig. 1. Examples of the reference signals

"Choose the main thing”. Distinguish keywords, formulate a few sentences that briefly reflect the essence of the text. The ability to generalize and highlight the main thing in the educational material is assessed.

"Question-answer". To divide students into several teams, each of which makes questions on the content of the text and answers the questions of rivals. The quantity and quality of questions and answers are estimated based on knowledge of the text.

"Syllabus". To summarize on separate sheets the contents of each section in several abstracts, exchange notes with another student, compose a sequence of them that correctly reflects the contents of the text. The correctness of the syllabus is estimated.

"Error". From two proposed passages find the text with erroneous statements and correct them. The number of inaccuracies found in the text and the correctness of their correction are estimated.

"Retelling in a circle". To reproduce the content of the text in parts by each student. The accuracy of the retelling is evaluated.

\section{Professional skills construction}

At the second stage of the research, the authors asked students to evaluate their skills. The questionnaire showed that $30 \%$ of the students surveyed have difficulty calculating the measurement uncertainty during term and diploma design, as well as solving problems requiring uncertainty calculation while studying interrelated disciplines. $18 \%$ replied that they could not create a budget of uncertainty by themselves. $70 \%$ noted that they would like to get more practical examples of such tasks. Thus, the problem stated by other authors has received one more confirmation.

Based on the method proposed in [2], it was decided to construct students' professional skills according to a three-stage model: basic tasks of full certainty for testing the methodology for evaluating the measurement result and its uncertainty; professional tasks with partial uncertainty ("case study"); complex interdisciplinary tasks with complete uncertainty (project method). At the same time, elements of e-learning were used at all stages (mind maps, interactive videos, simulators).

The choice of specific pedagogical technologies was also influenced by the extent to which, with their help, metrology students can develop the general competencies specified in the standard of higher education [8]:

- ability to evaluate and ensure the quality of work performed;

- ability to apply professional knowledge and skills in practice;

- the ability to search, process and analyze information from various sources;

- the ability to learn and master modern knowledge;

- ability to be critical and self-critical.

\section{Case study}

The case study analysis method is especially effective in contextual learning for improving skills and gaining practical experience in solving professional problems individually and in a group. The defining feature of the cases is the creation of a problem situation based on the facts from real life or professional activity. This make it to differ significantly from traditional educational tasks and exercises [9].

This method, in our opinion, is particularly suitable for studying measurement uncertainty since the methodology for evaluating the measurement result and its uncertainty proposed in GUM [5] represents the abovementioned practical task of the professional work of a metrological engineer. In this case, the case may be the entire procedure for estimating the measurement uncertainty, or each of its stages. The case study method also has the following advantage: as a result, students receive a suitable solution that can be applied in similar circumstances. The following are examples of such cases.

Case 1. For a few reasons, for example to save production costs, the measurement technique allows no more than three measurements of the same value. In this case, the measurement result can be defined as the arithmetic mean, mode or median of the obtained values, but the statistical methods for estimating the uncertainty with such a sample size will give a very rough estimate. How to rationally represent measurement uncertainties in this case?

Case 2. Since some operational parameters of the equipment to be monitored can, can be measured only 
once, it is necessary to evaluate the uncertainty of a single measurement. How to do it?

Case 3. A TKM-459M type hardness tester carried out a series of measurements and obtained the following results $123 \mathrm{HB} ; 130 \mathrm{HB}, 121 \mathrm{HB}, 133 \mathrm{HB}, 127 \mathrm{HB}$. At the same time, the hardness tester operation manual indicates that its absolute error does not exceed $\pm 10 \mathrm{HB}$. How to evaluate the measurement uncertainty in this case?

Case 4. Choose a measuring instrument to control the length of the product $\mathrm{L}=900 \mathrm{~mm}$, manufactured according to IT11 qualification (ISO 286-2: 2010).

\section{Project Method}

The difference between the project method and the "case study" is that students are offered a more voluminous task, the solution of which will require the application of skills from various fields, and the result is ready for the real development [10]. The project can be a term paper, an annual practice report, a final certification on a discipline, it can also be replaced, depending on the volume, with several practical or laboratory works. This method is good for developing skills of independent work, work in a group, in a pair, as well as for individualizing learning. In this case, the calculation of measurement uncertainty will be one of the stages of the project, integrated into professional activities. The following are examples of assignments for such projects.

Project 1. At the gas distribution station "Novopskovsk industrial site of the Severodonetsk linear production department of the main gas pipelines of the "Kharkovtransgaz" branch", pressure gauges of the DM05100, BE-16RB, MTI types are used to control gas pressure. The metrological service of the station was qualified to calibrate these instruments. Suggest necessary improvements in the metrological support of this process. The calculation of the measurement uncertainty should be contained in the created calibration procedure and carried out in the process of testing it.

Project 2. The conformity assessment organization turned to an accredited laboratory with the desire to test the wheeled vehicle for compliance with uniform technical requirements. The object is a 2013 Daewoo
Lanos car with an engine capacity of 1.51 . Fill out all the necessary documents. The results of the calculation of the measurement uncertainty shall be indicated in the test report.

Project 3. Design a digital device for measuring mass from 0 to $5000 \mathrm{~kg}$ based on the comparison method using a strain gauge transducer. Prepare the necessary documents for its metrological certification. The calculation of the measurement uncertainty should be contained in the protocol of the studied metrological characteristics, as well as in the compiled measurement procedure.

Thus, the project method allows you to bring the learning process closer to the future professional activities of metrology students, as well as develop their skills in self-organization, managerial, independent work, skills in planning activities and teamwork.

\section{E-learning}

Modern technologies provide a wide range of information and communication tools for education: from e-learning systems to individual multimedia elements. The latter are most convenient for point application, where you need to solve a specific problem in the context of a particular discipline, and do not require drastic changes in the form of training, unlike e-course, SCORM packages, etc. According to said above, such pedagogical technologies as mind maps, interactive videos, and simulators were chosen.

The mind map proposed by the American educators B. DePorter and M. Hernacki [11] is based on the principle of cognitive visualization, which follows from the psychological patterns of the brain working on the perception, processing, and transmission of information. According to them, the efficiency of adoption is increased if the visualization in training performs not only an illustrative, but also a cognitive function, that is, cognitive graphic learning elements are used (Fig. 2).

The difference between a mind map and a reference signal is that usually it represents a larger semantic fragment, and has a standard construction principle, while the reference signal may have a different shape and a variable size of the didactic unit.

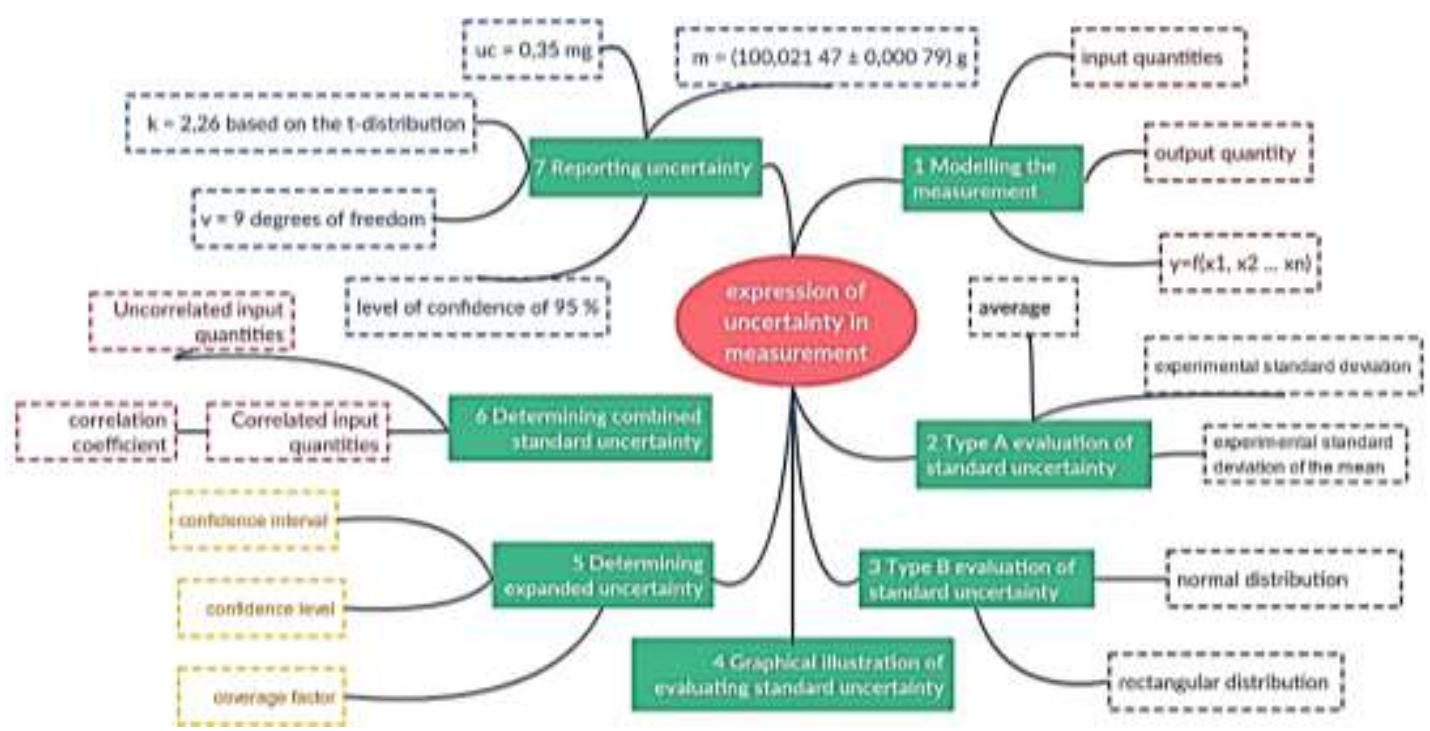

Fig. 2. An example of a mind map for the process of expressing measurement uncertainty 
Interactive videos are another way to engage students in active interaction with information (Fig. 3). With their help, the teacher can create interactive video tutorials by attaching polls, tests, open questions, links to other resources to them, as well as designing scenarios and learning paths. The main advantages of using interactive videos instead of the usual educational video materials include parallel monitoring of learning content development and overcoming students' passivity. The ways of using interactive video resources are diverse: video instructions, quests, developing skills for solving problems, creating role-playing games, etc. [12].

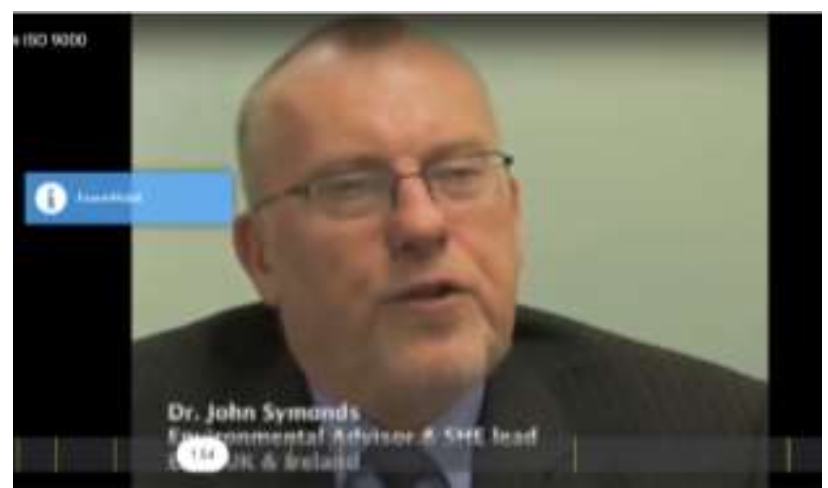

Fig. 3. Interactive video screenshot

Better opportunities for developing professional skills are provided by tools for creating electronic training materials. The most famous of them are Articulate Storyline, iSpring Suite, CourseLab, Adobe Captivate. All of them allow you to implement the learning path, include video, audio, graphics, tests, interactive simulators, interactivity of various types with automatic sending of results to the e-learning system. Fig. 4 presents an example of such a simulator for measurement uncertainty.

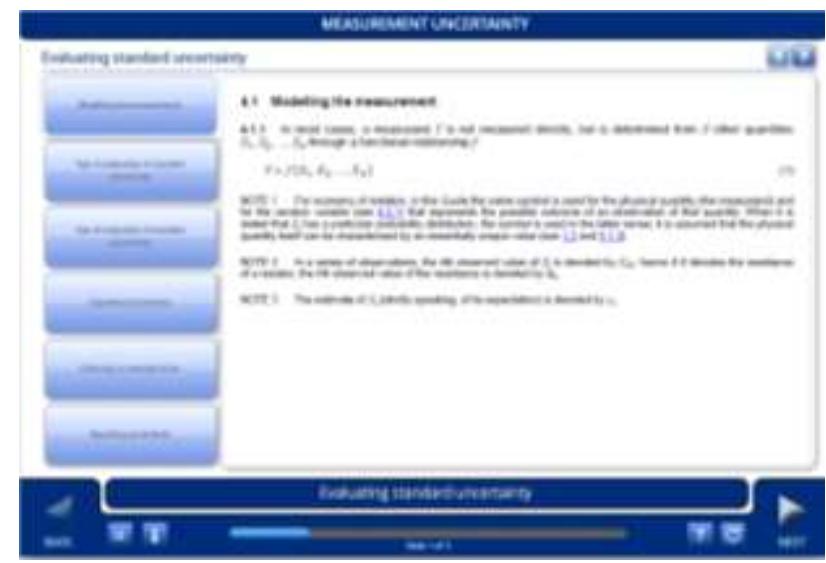

Fig. 4. CourseLab simulator for studying uncertainty of measurements

\section{Approbation}

The proposed pedagogical technologies were tested at the third stage of the study when training metrology students in the spring of 2019: 12 people in the control group and 13 in the experimental group. The following control characteristics of the group were identified:

- quantitative - the quality and success of training

- qualitative (highlighted in accordance with [13]) practical skills, theoretical knowledge, social activity, interest in discipline, motivation for learning, connection with the profession.

In both cases, the experiment was formative, onefactor, open, parallel, in vivo. At the same time, the control group studied the topic "Measurement Uncertainty" in the traditional way: a lecture of 90 minutes, laboratory work of 90 minutes, and independent work of 180 minutes. At the same time, the form, content, and degree of adoption of the material during the independent work of students by the teacher was not checked.

The experimental group had to independently carry out the simulator and compile a GUM text mind map (180 $\mathrm{min}$ ), after which a lecture (45 min) was given, a seminar was held to develop theoretical material using the technology of working with educational literature (45 $\mathrm{min}$ ) and to solve basic problems and cases (45 min) and laboratory work on mechanical measurements (45 min). Instead of a test, students were asked to complete the project "Sharing the concepts of measurement uncertainty and error in various metrological tasks" as a final grade for the "Measurement Uncertainty and Error" module.

The learning outcomes are shown in tables 1 and 2 . In this case, anonymous questionnaire was used to evaluate quality indicators.

Since the sample size is quite small, it is difficult to reliably evaluate the distribution law of the control characteristics of the group. Then, to determine the statistical significance of the obtained results, it is advisable to use nonparametric methods, for example the Mann-Whitney criterion for independent samples [14]. The critical value of this criterion for the sample size $n_{l}=$ 12 and $n_{2}=13$ is $U=41$.

Thus, in comparison with the control group, the success of studying the measurement uncertainty increased by $16 \%$, and the quality - by $12 \%\left(U_{\min }=40,5\right)$. It was also found that among the qualitative indicators significant changes were in the "theoretical knowledge" by $25 \%\left(U_{\min }=38\right)$, «practical skills» on $29 \%\left(U_{\min }=\right.$ $23)$, «connection with profession» on $17 \%\left(U_{\min }=39,5\right)$. For «social activity» $\left(U_{\min }=46,5\right)$ and «interest to discipline» $\left(U_{\min }=49\right)$ and «learning motivation» $\left(U_{\min }=\right.$ 49,5) indicators the difference is not statistically significant.

Table 1

Quantitative results of studying measurement of uncertainty

\begin{tabular}{|l|l|l|}
\hline \multirow{2}{*}{} & \multicolumn{2}{|c|}{ Number of students } \\
\cline { 2 - 3 } & Control group & Experimental group \\
\hline A (90-100) & 1 & 3 \\
\hline B (82-89) & 2 & 3 \\
\hline C (75-81) & 2 & 1 \\
\hline D (67-74) & 2 & 4 \\
\hline E (60-66) & 3 & 2 \\
\hline F (35-59) & 2 & 0 \\
\hline
\end{tabular}


Table 2

Qualitative results of studying measurement of uncertainty *

\begin{tabular}{|c|c|c|c|c|c|c|c|c|c|c|}
\hline \multicolumn{11}{|c|}{ Theoretical knowledge } \\
\hline Self-assessment on 1-10 scale & 1 & 2 & 3 & 4 & 5 & 6 & 7 & 8 & 9 & 10 \\
\hline Control group & - & - & 4 & 5 & 2 & 1 & - & - & - & - \\
\hline Experimental group & - & - & 1 & 3 & 5 & 3 & 1 & - & - & - \\
\hline \multicolumn{11}{|c|}{ Practical skills } \\
\hline Self-assessment on 1-10 scale & 1 & 2 & 3 & 4 & 5 & 6 & 7 & 8 & 9 & 10 \\
\hline Control group & - & - & 1 & 2 & 5 & 4 & - & - & - & - \\
\hline Experimental group & - & - & - & - & 2 & 5 & 4 & 2 & - & - \\
\hline \multicolumn{11}{|c|}{ Social activity } \\
\hline Self-assessment on 1-10 scale & 1 & 2 & 3 & 4 & 5 & 6 & 7 & 8 & 9 & 10 \\
\hline Control group & - & 1 & 5 & 5 & 1 & - & - & - & - & - \\
\hline Experimental group & - & - & 2 & 8 & 3 & - & - & - & - & - \\
\hline \multicolumn{11}{|c|}{ Connection with profession } \\
\hline Self-assessment on 1-10 scale & 1 & 2 & 3 & 4 & 5 & 6 & 7 & 8 & 9 & 10 \\
\hline Control group & - & - & - & 1 & 2 & 5 & 4 & - & - & - \\
\hline Experimental group & - & - & - & - & 1 & 3 & 5 & 3 & 1 & - \\
\hline \multicolumn{11}{|c|}{ Interest to discipline } \\
\hline Self-assessment on 1-10 scale & 1 & 2 & 3 & 4 & 5 & 6 & 7 & 8 & 9 & 10 \\
\hline Control group & - & - & 1 & 2 & 4 & 3 & 2 & - & - & - \\
\hline Experimental group & - & - & - & 1 & 2 & 6 & 4 & - & - & - \\
\hline \multicolumn{11}{|c|}{ Learning motivation } \\
\hline Self-assessment on 1-10 scale & 1 & 2 & 3 & 4 & 5 & 6 & 7 & 8 & 9 & 10 \\
\hline Control group & - & - & 3 & 2 & 5 & 2 & - & - & - & - \\
\hline Experimental group & - & - & 1 & 1 & 6 & 4 & 1 & - & - & - \\
\hline
\end{tabular}

*number of students, who chosen an answer

\section{Conclusion}

The experience of teaching measurement uncertainty in a higher educational institution has shown that there is a need for more professional and practical specialization in the study of this topic by metrology students. To solve this problem, active teaching methods were chosen, the use of which is easily integrated into the existing conditions of the educational process.

The experimental results suggest that the chosen pedagogical technologies contribute to an increase in the quality and success of the study of measurement uncertainty by metrological students, their theoretical knowledge, and practical skills. At the same time, social activity, interest in discipline and motivation for learning have not changed.

In this regard, in the future it seems necessary to apply the training method in cooperation in the context of the competency-based approach. This will make it possible to evaluate the indicator "practical skills" not as a whole, but as a complex of constituent competencies. Such an approach will make it possible to choose pedagogical technologies more accurately for the uniform development of each competency.

\section{Анотація}

У статті розглядається проблема активізації пізнавальної діяльності студентів, а також максимально ефективного використання навчального часу в процесі вивчення ними поняття невизначеності вимірювань та ії розрахунку. Опитування 56 студентів показав, що 80\% з них вважають цю тему найбільш складною в курсі «Основи метрології», а $60 \%$ відповіли, що їм потрібно більше часу для ії засвоєння, ніж дано робочою програмою дисципліни. Для усунення цього недоліку студентам були запропоновані методики роботи $з$ навчальною літературою: опорні сигнали і бліц-гри. Ці педагогічні технології спрямовані на те, щоб поглибити розуміння теорії за той же час. Анкетування з приводу отриманих навичок також показало, що $30 \%$ опитаних студентів відчувають труднощі при розрахунку невизначеності вимірювань під час курсового та дипломного проектування, а також при вирішенні прикладних задач, що вимагають розрахунку невизначеності, під час вивчення взаємопов'язаних дисциплін. 18\% відповіли, що не можуть самостійно скласти бюджет невизначеності. $70 \%$ відзначили, що хотіли б отримати більше практичних прикладів виконання таких завдань. Для вирішення цих проблем автори пропонують використовувати метод кейсів, метод проектів, а також елементи електронного навчання (карти пам'яті, інтерактивні відео, тренажери). Результати педагогічного експерименту показали, що завдяки цьому успішність вивчення невизначеності вимірювань збільшилася на $16 \%$, а якість - на $12 \%$.

Ключові слова: метод проектів, метод кейсів, невизначеність вимірювань, опорний сигнал, електронне навчання.

\section{Аннотация}

В статье рассматривается проблема активизации познавательной деятельности студентов, а также максимально эффективного использования учебного времени в процессе изучения ими понятия неопределенности измерений и ее расчета. Опрос 56 студентов показал, что 80 \% из них считают эту тему наиболее сложной в курсе «Основы метрологии», а $60 \%$ ответили, что им нужно больше времени для ее освоения, чем дано рабочей программой дисциплины. Для устранения этого недостатка студентам были предложены методики работы с учебной литературой: опорные сигналы и блиц-игры. Эти педагогические технологии направлены на то, чтобы углубить понимание теории за то же время. Анкетирование по поводу 
полученных навыков также показало, что $30 \%$ опрошенных студентов испытывают трудности при расчете неопределенности измерений во время курсового и дипломного проектирования, а также при решении прикладных задач, требующих расчета неопределенности, во время изучения взаимосвязанных дисциплин. 18 \% ответили, что не могут самостоятельно составить бюджет неопределенности. 70 \% отметили, что хотели бы получить больше практических примеров выполнения таких задач. Для решения этих проблем авторы предлагают использовать метод кейсов, метод проектов, а также элементы электронного обучения (карты памяти, интерактивные видео, тренажеры). Результаты педагогического эксперимента показали, что благодаря этому успешность изучения неопределенности измерений увеличилась на $16 \%$, а качество - на $12 \%$. обучение

Ключевые слова: метод проектов, метод кейсов, неопределенность измерений, опорный сигнал, электронное

\section{References}

1. Guzeev V. I., Syireyschikova N. V. Rol innovatsionnyih tehnologiy obucheniya pri podgotovke spetsialistov $\mathrm{v}$ oblasti metrologii, standartizatsii i sertifikatsii [The role of innovative educational technologies in the training of specialists in the field of metrology, standardization and certification]. Vestnik YuUrGU. Seriya «Kompyuternyie tehnologii, upravlenie, radioelektronika». 2015. Vol. 15. Iss. 1. PP. 91-99 (in Russian).

2. Goncharova Ya. S., Fedorchenko I. S. Obuchenie bakalavrov v tehnicheskom vuze: sozdanie uchebno-professionalnyih situatsiy v protsesse prepodavaniya distsiplinyi «Metrologiya, standartizatsiya i sertifikatsiya» [Education of bachelors in a technical university: the creation of educational and professional situations in the process of teaching the discipline "Metrology, standardization and certification"]. Vestnik KrasGAU. 2014. Vol. 6. PP. 312-314 (in Russian).

3. Lesnaya V. I. Problemyi prepodavaniya metrologii na etape reformirovaniya rossiyskoy sistemyi obespecheniya edinstva izmereniy [Problems of teaching metrology at the stage of reforming the Russian system for ensuring the uniformity of measurements]. Vologdinskie chteniya. 2012. Vol. 80. PP. 337-338 (in Russian).

4. Berzhinskaya M. V., Golubinskiy Yu. M., Nazarova I. T. Vvedenie ponyatiya neopredelennosti izmereniya $\mathrm{v}$ distsiplinyi inzhenernogo napravleniya [Introduction of the concept of measurement uncertainty in engineering disciplines]. Izmerenie. Monitoring. Upravlenie. Kontrol. 2018. Vol. 1 (23). PP. 5-10 (in Russian). DOI 10.21685/23075538-2018-1-1

5. State Standard ISO/IEC Guide 98-3:2018. Uncertainty of measurement - Part 3: Guide to the expression of uncertainty in measurement (GUM:1995) (ISO/IEC Guide 98-3:2008, IDT). Kyiv: DP UkrNDNTs, 2020. 272 c (in Ukrainian).
6. Zaharov I.P. Neopredelennost izmereniy dlya chaynikov i....nachalnikov: Uchebnoe posobie [Measurement Uncertainty for Dummies and .... Supervisors: A Training Manual]. Harkov, 2013. 36 p. (in Russian).

7. Shatalov V. F. Pedagogicheskaya proza [Educational prose]. Arhangelsk: Sev.-Zap. kn. izd-vo. 1990. 384 p.

8. Ministry of Education and Science of Ukraine (2018, Nov. 19). Order No. 1263, On Approval of the Standard of Higher Education in the specialty 152 «Metrology and InformationMeasurement Technology» for the first (bachelor) level of higher education. (in Ukrainian). Available at: https://mon.gov.ua/ua/npa/pro-zatverdzhennya-standartuvishoyi-osviti-za-specialnistyu-152-metrologiya-tainformacijno-vimiryuvalna-tehnika-dlya-pershogobakalavrskogo-rivnya-vishoyi-osviti.(accessed 07.07.2020).

9. N. Prabhu Kishore, N. Alekhya. An Introduction to Active Learning Stratagies. Educreation Publishing, 2018. 97 p.

10. Phillip C. Wankat, Frank S. Oreovicz. Teaching Engineering. Purdue University Press, 2015. 450 p.

11. DePorter B., Hernacki M. Quantum learning: Unleashing the Genius in You. A Dell Trade Paperback, 1992. 368 p.

12. Zhang D., Zhou L., Briggs R. O., Nunamaker J. F Instructional video in e-learning: Assessing the impact of interactive video on learning effectiveness. Information \& Management. 2006. V. 43, Iss. 1. PP. 15-27. https://doi.org/10.1016/j.im.2005.01.004.

13. Bartasevich I. G. Sistema kriteriev kachestva obucheniya studentov $\mathrm{v}$ vyisshem uchebnom zavedenii [The system of criteria for the quality of student learning in higher education]. Vestnik Astrahanskogo gosudarstvennogo tehnicheskogo universiteta. 2008. Vol. 3. PP. 217-220 (in Russian).

14. Kulaichev A. P. Metodyi i sredstva kompleksnogo analiza dannyih: uchebnoe posobie [Methods and tools for integrated data analysis: tutorial]. Moskva, Rossiya: FORUM: INFRAM, 2017. 484 p. (in Russian). 